FOLIA POMERANAE UNIVERSITATIS TECHNOLOGIAE STETINENSIS

Folia Pomer. Univ. Technol. Stetin., Oeconomica 2018, 344(91)2, 21-32

Zdzisław KES, Olena CHURIUKOVA*

\title{
KALKULACJA KOSZTÓW OSOBOWYCH NAUCZYCIELI AKADEMICKICH
}

\section{CALCULATION OF PERSONAL COSTS OF ACADEMIC TEACHERS}

\author{
Katedra Rachunku Kosztów, Rachunkowości Zarządczej i Controllingu, Uniwersytet Ekonomiczny \\ we Wrocławiu, ul. Komandorska 118/120, 53-345 Wrocław, e-mail: zdzislaw.kes@ue.wroc.pl \\ *Dział Controllingu, Uniwersytet Ekonomiczny we Wrocławiu, \\ ul. Komandorska 118/120, 53-345 Wrocław, e-mail: olena.churiukova@ue.wroc.pl
}

\begin{abstract}
Summary. Effective management of a public university requires processing of many data. The profitability of particular types of activity is determined by their revenues and costs. The costs of didactics consist mainly of personnel costs (wages plus salary overheads) of professors, adjuncts, assistants, lecturers and others. Proper processing of cost data requires implementation of advanced calculation methods. Therefore, the purpose of the article is to present the procedure for calculating the personnel costs of academic teachers at a public university. The procedure has the option of determining the cost of education within individual fields of study. Based on the case study, aspects of the functioning of the cost account, problems of obtaining the data needed for the calculation and rules of their processing were presented. As an example, the University of Economics in Wroclaw was used, while the data used in the calculation model came from the academic year 2016/2017.
\end{abstract}

Słowa kluczowe: koszty kształcenia, działalność dydaktyczna, wynagrodzenia osobowe, USOS. Key words: education costs, didactic activity, personal salary, USSS.

\section{WSTĘP}

Zarządzanie uczelnią publiczną jest bezpośrednio związane ze sterowaniem działalnością dydaktyczną. Efektywne zarządzanie wymaga dostarczenia danych dotyczących m.in. przychodów i kosztów poszczególnych rodzajów działalności. Systemem przetwarzającym dane kosztowe dla różnych celów jest rachunek kosztów. Jednym z elementów tego rachunku jest kalkulacja polegająca na ustalaniu kosztu jednostkowego określonego nośnika kosztów. W przypadku uczelni mogą to być np. koszty wykształcenia absolwenta na określonym kierunku, specjalności, w trybie, formie i stopniu studiów.

W działalności dydaktycznej uczelni kalkulacja kosztów jest sprawą złożoną. Składa się na to wiele czynników, np.: złożoność siatek godzinowych poszczególnych kierunków i specjalności, trudności z dostępem do dokładnych danych dotyczących wykorzystania zasobów uczelni czy problemy z określeniem kosztów osobowych w określonych przekrojach. Zdaniem autorów niniejszej publikacji koniecznością staje się wypracowanie odpowiedniego modelu kalkulacji kosztów działalności dydaktycznej.

Celem niniejszego artykułu jest prezentacja autorskiego podejścia do kalkulacji kosztów osobowych nauczycieli akademickich na uczelni, pozwalającego na ustalanie kosztochłonności poszczególnych kierunków. 
W części pierwszej artykułu krótko scharakteryzowano rachunek kosztów na uczelni publicznej. W drugiej części znajduje się opis studium przypadku. W trzeciej części autorzy dokonują charakterystyki danych źródłowych wykorzystywanych w kalkulacji. Następnie zaprezentowano procedurę rozliczania kosztów osobowych pracowników dydaktycznych na kierunki. Artykuł kończą podsumowanie i propozycja kierunków dalszej dyskusji.

\section{MATERIA I METODY}

Zagadnienia kosztowe oraz wdrożeniowe w zakresie procedur kalkulacyjnych należą do złożonego obszaru poznawczego. Do tego dochodzi specyfika działalności badanych podmiotów polegająca na świadczeniu usług dydaktycznych oraz realizacji projektów naukowych. Zagadnienia poruszane w artykule wymagają dużej świadomości kosztowej (np. znajomości czynników kosztotwórczych, biegłego posługiwania się różnymi podejściami do alokacji kosztów, rozumienia istoty wsparcia procesów decyzyjnych przez informacje kosztowe). Zatem zbudowanie procedury kalkulacji kosztów wymagało prac polegających na:

- studiowaniu literatury z zakresu rachunku kosztów i kalkulacji kosztów, w szczególności w obszarze szkolnictwa wyższego;

- przeglądzie aktów prawnych dotyczących finansów uczelni publicznych;

- przeglądzie dokumentacji wewnętrznej Uniwersytetu Ekonomicznego we Wrocławiu dotyczącej zasad rachunkowości (w tym zarządzenia Rektora);

- analizie systemów informatycznych na Uniwersytecie Ekonomicznym we Wrocławiu pod kątem dostępu do danych kosztowych i ilościowych związanych z działalnością dydaktyczną;

- przeprowadzeniu kwerend wśród pracowników służb księgowych, controllingowych, odpowiedzialnych za poszczególne obszary sprawozdawczości wewnętrznej, służących do ustalenia wszystkich czynników wpływających na koszty kształcenia oraz ich roli w procesie kalkulacji;

- budowie i testowaniu poszczególnych rozwiązań pozwalających na kalkulację kosztów kształcenia;

- wyborze optymalnego sposobu kalkulacji.

W trakcie opracowywania zasad kalkulacji kosztów wykorzystano przypadek Uniwersytetu Ekonomicznego we Wrocławiu. Autorzy brali czynny udział w pracach nad modelem rozliczeniowym kosztów w badanej jednostce. Dane potrzebne do weryfikacji modelu obejmowały rok akademicki 2016/2017; pochodziły z systemów finansowych, kadrowych oraz z uniwersyteckiego systemu obsługi studiów (USOS) Uczelni.

\section{ISTOTA RACHUNKU KOSZTÓW NA UCZELNI PUBLICZNEJ}

Rachunek kosztów stanowi zasadniczą część systemu informacyjnego każdego przedsiębiorstwa. Jego zadaniem jest m.in. dostarczanie danych do sprawozdań finansowych, przygotowywanie informacji kosztowych dla odbiorców wewnętrznych przedsiębiorstwa na temat planowania i kontroli kosztów, pomoc w podejmowaniu decyzji cenowych oraz umożliwienie zarządzania rentownością produktów, klientów (Świderska 2008). Jedną 
z procedur rachunku kosztów jest kalkulacja kosztów. Kalkulacja kosztów stanowi „[...] działanie zmierzające do ustalenia kosztu obiektu kalkulacji, wraz ze wskazaniem struktury jego komponentów" (Świderska 2008, s. 40).

Ustalenie kosztów jednostkowych pracy nauczycieli akademickich wymaga uwzględnienia aspektów związanych z krajowymi regulacjami prawnymi, specyfiki działalności uczelni, w tym dostępnych źródeł danych oraz doboru odpowiedniej metody kalkulacji kosztów,

W rachunku kosztów uczelni publicznej znaczącą rolę odgrywa prawo o szkolnictwie wyższym (Ustawa z dnia 27 lipca 2005 r. Prawo o szkolnictwie wyższym), w którym koszty mogą być przypisane do działalności: dydaktycznej, naukowo-badawczej oraz gospodarczo wyodrębnionej. Zgodnie z Rozporządzeniem Rady Ministrów z dnia 18 grudnia 2012 roku w sprawie szczegółowych zasad gospodarki finansowej uczelni publicznej do kosztów działalności dydaktycznej można odnieść koszty ponoszone na: procesy dydaktyczne, kształcenie i rozwój kadry naukowej, utrzymanie uczelni publicznej, w tym koszty remontów (z wyjątkiem domów studenckich i stołówek), prowadzenie innych działań podejmowanych przez uczelnię publiczną w ramach działalności dydaktycznej.

Te koszty można podzielić na bezpośrednie i pośrednie (Miłosz 2003). Do bezpośrednich kosztów działalności dydaktycznej można odnieść przede wszystkim wynagrodzenia wraz z narzutami nauczycieli akademickich (koszty osobowe). Do pośrednich kosztów odnoszone są koszty: infrastruktury dydaktycznej (budynków, pomieszczeń, komputerów, laboratoriów), zużycia materiałów i energii, usług wspierających proces dydaktyczny (np. pracę administracji uczelni, biblioteki).

Rozporządzenie Rady Ministrów z dnia 18 grudnia 2012 roku w sprawie szczegółowych zasad gospodarki finansowej uczelni publicznej (RRM 2012) pozostawia możliwość określenia funkcjonowania rachunku koszów według uznania rektorów, zgodnie z zasadami rachunkowości. Według rozporządzenia:

1. Koszty działalności dydaktycznej rozlicza się, w tym ewidencjonuje, z podziałem na koszty kształcenia na studiach stacjonarnych i niestacjonarnych, na koszty pozostałej działalności dydaktycznej (RRM 2012, §4).

2. Sposób rozliczania kosztów bezpośrednich działalności dydaktycznej, w tym kosztów wynagrodzeń, których na bieżąco nie można zakwalifikować do kosztów studiów stacjonarnych, niestacjonarnych lub do pozostałej działalności dydaktycznej, stanowi element zasad (polityki) rachunkowości i może być ustalony z uwzględnieniem możliwości rozliczania tych kosztów odpowiednio do liczby godzin dydaktycznych realizowanych w ramach studiów stacjonarnych, niestacjonarnych lub pozostałej działalności dydaktycznej (RRM 2012, §19, ust. 2).

$\mathrm{Na}$ każdej Uczelni publicznej istnieją własne zasady polityki rachunkowości, które powstały na podstawie Ustawy z dnia 29 września 1994 o rachunkowości (UoR 1994).

Specyfika działalności uczelni determinuje strukturę kosztów. Świadczą o tym badania Małysa (2016), który stwierdził, że średnio 84\% kosztów podstawowej działalności operacyjnej uczelni stanowią koszty dydaktyki. Przy czym dominującą rolę odgrywają wynagrodzenia wraz z narzutami ${ }^{1}$. Udział tego składnika w kosztach operacyjnych może

1Do tej kategorii zalicza się m.in.: wynagrodzenia z osobowego i bezosobowego funduszu pracy, składki do ZUS, narzut z tytułu odpisu na Zakładowy Fundusz Świadczeń Socjalnych, narzut z tytułu dodatkowego wynagrodzenia rocznego, narzut z tytułu Funduszu Nagród Rektora. 
przyjmować na polskich uczelniach wartości z przedziału od 58\% do 82\% (Małys 2016). W związku z tym odpowiednia kalkulacja kosztów osobowych jest kluczowym czynnikiem wpływającym na jakość alokacji kosztów działalności dydaktycznej uczelni. Czynników wpływających na jakość kalkulacji, poza doborem metody, należy szukać w odpowiednim grupowaniu, ewidencji i rozliczaniu kosztów, identyfikacji obiektów kalkulacyjnych oraz w prawidłowych działaniach obliczeniowych.

Metodą kalkulacji, która pozwala na obliczenie kosztu jednostkowego kształcenia w szkole wyższej, jest kalkulacja doliczeniowa zleceniowa. To podejście zakłada indywidualne traktowanie każdego obiektu kalkulacji, którym mogą być pojedyncze produkty, a także ich serie. W tej metodzie koszty bezpośrednie są rejestrowane w przekroju poszczególnych obiektów kalkulacyjnych. Natomiast koszty pośrednie alokowane są do obiektów kosztowych na podstawie odpowiednich kluczy rozliczeniowych. Łączne koszty bezpośrednie i pośrednie danego obiektu kalkulacyjnego mogą być podzielone przez odpowiednią liczbę jednostek kalkulacyjnych otrzymanych w ramach danego zlecenia, co umożliwia ustalenie kosztu jednostkowego.

W przypadku działalności dydaktycznej obiektami kalkulacyjnymi mogą być poszczególni studenci, grupy studentów, grupy seminaryjne czy administracyjne. Jednostki dydaktyczne, takie jak poszczególne ćwiczenia, laboratoria, wykłady, również mogą być traktowane jak obiekty kalkulacyjne. Podobnie jak poszczególne kierunki, specjalności, tryby, roczniki czy semestry.

Na potrzeby niniejszego opracowania jako obiekt kalkulacyjny zdefiniowano każdą edycję kierunku studiów danego trybu i stopnia. W tym przypadku edycja jest traktowana jak zlecenie w przedsiębiorstwie produkcyjnym oraz ma cechy podobne do projektów wieloletnich. Koszty ujęte w przekroju danej edycji przyrastają od pierwszego roku studiów do ostatniego. Dysponując danymi dotyczącymi całej edycji, można określić koszt jednostkowy wykształcenia absolwenta danego kierunku na studiach stacjonarnych lub niestacjonarnych stopnia pierwszego bądź drugiego.

Dane potrzebne do obliczeń są rozporoszone i znajdują się w różnych informatycznych systemach dziedzinowych. Koszty wynagrodzeń wraz z narzutami są gromadzone w systemach finansowo-księgowych, dane nt. obsady stanowisk nauczycieli znajdują się systemach kadrowo-płacowych, a liczba godzin, przepracowanych przez każdego pracownika, w ramach poszczególnych przedmiotów oraz studentów są umieszczone w systemach typu USOS. Dostęp do poszczególnych baz danym jest czynnikiem niezbędnym, aby możliwe było obliczenie kosztów rzeczywistych w ramach określonego obiektu kosztowego. W dalszej części opracowania przedstawiono aspekty techniczne i merytoryczne związane z procesem kalkulacji kosztów osobowych w przekroju kierunków kształcenia.

\section{OPIS STUDIUM PRZYPADKU}

Na potrzeby opracowania modelu kalkulacji kosztów działalności dydaktycznej na uczelni publicznej w obszarze kosztów osobowych zostały wykorzystane dane Uniwersytetu Ekonomicznego we Wrocławiu. Uniwersytet Ekonomiczny we Wrocławiu składa się z:

- Wydziału Nauk Ekonomicznych, 
- Wydziału Zarządzania, Informatyki i Finansów,

- Wydziału Inżynieryjno-Ekonomicznego,

- Wydziału Ekonomii, Zarządzania i Turystyki w Jeleniej Górze.

W omawianej jednostce w roku 2016/2017 studiowało ok. 13500 studentów, a zatrudnionych było ok. 1150 pracowników, w tym 600 pracowników dydaktycznych.

$\mathrm{Na}$ Uniwersytecie zasady polityki rachunkowości zostały wprowadzone Zarządzeniem Rektora w 2009 roku. W 2013 roku Zarządzeniem nr 107/2013 Rektora z dnia 31 grudnia (Zarz. 107/2013) dotyczącym zasad polityki rachunkowości zmodyfikowano zasady dotyczące rozliczenia kosztów i przychodów. Zmiany te były wymuszone Rozporządzeniem Rady Ministrów z dnia 18 grudnia 2012 roku w sprawie szczegółowych zasad gospodarki finansowej uczelni publicznej (RRM 2012). W szczególności zmiany te dotyczyły kont zespołu „5”, przeznaczonych do ewidencji i rozliczania kosztów działalności dydaktycznej, badawczej oraz działalności pomocniczej, a także kosztów pośrednich.

Według znowelizowanego zarządzenia Uczelnia ujmuje koszty w przekroju rodzajów działalności (na kontach zespołu „5”), z wyodrębnieniem finansowania z dotacji z budżetu państwa oraz z przychodów własnych. W ramach kosztów działalności dydaktycznej na odpowiednio wydzielonych kontach analitycznych ujmuje się operacje gospodarcze z podziałem na koszty związane z procesem dydaktycznym i pozostałe koszty dydaktyczne. W ramach działalności badawczej ewidencja uwzględnia poszczególne źródła finansowania. Ponadto wyodrębnia się konta kosztów działalności pomocniczej, kosztów wydziałowych, kosztów ogólnych uczelni. Konta powiązane z działalnością dydaktyczną umożliwiają rozliczanie kosztów z podziałem na koszty kształcenia na studiach stacjonarnych i niestacjonarnych, w ramach poszczególnych wydziałów oraz pozostałe koszty dydaktyczne. Koszty bezpośrednie w ramach działalności dydaktycznej, w tym koszty wynagrodzeń, których na bieżąco nie można zakwalifikować do kosztów studiów stacjonarnych, niestacjonarnych lub do pozostałej działalności dydaktycznej, rozlicza się raz na koniec roku obrotowego odpowiednio do liczby godzin dydaktycznych realizowanych w ramach studiów stacjonarnych i niestacjonarnych lub pozostałej działalności dydaktycznej. Koszty pośrednie obejmują koszty wydziałowe i ogólnouczelniane (Zarz. 107/2013).

W Rozporządzeniu Ministra Nauki i Szkolnictwa Wyższego z dnia 2 grudnia 2016 r. w sprawie warunków wynagradzania za pracę i przyznawania innych świadczeń związanych z pracą dla pracowników zatrudnionych na uczelni publicznej (Rozp. 2016) określone są szczegółowe zasady wynagradzania pracowników dydaktycznych wynikające z zawartego stosunku pracy. Wysokość wynagrodzeń zasadniczych jest określona w umowie o pracę. Wynagrodzenia zasadnicze zawierają w sobie stałe składniki i są wypłacane co miesiąc „z góry”. Również pracownicy dydaktyczni otrzymują dodatki do wynagrodzenia zasadniczego, takie jak dodatek funkcyjny, dodatek od stażu pracy lub dodatek specjalny, który przyznaje się tylko na czas określony.

Ważnym składnikiem wynagrodzeń pracowników dydaktycznych jest zapłata za godziny ponadwymiarowe. Wymiar tych godzin nie może przekraczać dla pracowników naukowo-dydaktycznych 1/4, a dla pracowników dydaktycznych 1/2 wymiaru obowiązków dydaktycznych. W Rozp. 2016 podane są tylko przybliżone obliczenia stawek godzin ponadwymiarowych. Każda uczelnia publiczna ma swoje ustalone stawki za godziny 
ponadwymiarowe. Na Uniwersytecie Ekonomicznym we Wrocławiu Uchwałą Senatu w sprawie zasad planowania i rozliczania zajęć dydaktycznych w roku akademickim 2017/2018 (Uchwała 2017) przyjęto następujące wymiary obowiązków dydaktycznych:

- profesor posiadający tytuł naukowy - 165 godzin;

- profesor nieposiadający tytułu naukowego - 195 godzin;

- adiunkt ze stopniem naukowym doktora hab. - 195 godzin;

- profesor wizytujący - 120 godzin;

- adiunkt ze stopniem doktora, asystent - 225 godzin;

- starszy wykładowca ze stopniem doktora - 330 godzin;

- wykładowca, starszy wykładowca bez stopnia naukowego - 360 godzin;

- lektor, instruktor - 540 godzin.

Pensum dla rektora, prorektorów, dziekanów i prodziekanów, zgodnie z uchwałą, jest pomniejszone o 45 godzin. Osobno rektor ustała obniżenie pensum dla członków Rady Głównej Nauki i Szkolnictwa Wyższego, Polskiej Komisji Akredytacyjnej oraz Centralnej Komisji ds. Stopni i Tytułów. Obniża się również pensum dla kierowników projektów badawczych według otrzymanego finansowania na ten cel.

Na podstawie Ustawy z dnia 27 lipca 2005 r. Prawo o szkolnictwie wyższym i Rozp. 2016 wszystkie stawki godzin ponadwymiarowych pracowników dydaktycznych zatrudnionych na Uniwersytecie Ekonomicznym we Wrocławiu są wyliczane w zarządzeniu Rektora (Zarz. 64/2017) i kształtują się w zależności od stanowiska i tytułu naukowego w przedziale od $48 \mathrm{z} \nmid / \mathrm{h}$ do $98 \mathrm{z}$ /h. Wszystkie wypłaty związane z godzinami ponadwymiarowymi pracownicy dydaktyczni Uniwersytetu Ekonomicznego we Wrocławiu otrzymują raz na rok.

Dyskusyjny jest podział kosztów osobowych pracowników zatrudnionych na stanowiskach dydaktyczno-naukowych na część związaną z działalnością dydaktyczną oraz naukowobadawczą. Bez ewidencji czasu pracy ani obiektywnych wskaźników podziałowych każdy podział będzie kontrowersyjny. W opisywanym modelu kalkulacji nie przyjęto sztywnych zasad podziału. Do dyspozycji decydentów i użytkowników modelu kalkulacji pozostawiono określenie, jaka część wynagrodzeń jest wpisana w ciężar działalności dydaktycznej. Podział jest uzależniony od wskaźnika tzw. D/N. W prezentowanym przypadku przyjęto wartość tego wskaźnika na poziomie 100\%. Równolegle z modelem kalkulacji jest opracowywana aplikacja komputerowa, która posiada interfejs pozwalający na modyfikację wartości wskaźnika D/N. Pozwala to na przeprowadzanie dowolnych symulacji w zależności od potrzeb. Prace nad obiektywnym podziałem kosztów wynagrodzeń pracowników dydaktyczno-naukowych będą podejmowane w kolejnych etapach wdrażania rachunku kosztów na Uniwersytecie Ekonomicznym we Wrocławiu i zostaną zaprezentowane w kolejnych publikacjach autorów niniejszego opracowania.

\section{CHARAKTERYSTYKA ŹRÓDEŁ DANYCH WYKORZYSTYWANYCH W PROCEDURZE KALKULACJI}

$\mathrm{Na}$ potrzeby stworzenia modelu szacowania kosztów osobowych trzeba mieć wiele danych, które dotyczą: 
1) danych osobowych pracowników dydaktycznych ( $z$ uwzględnieniem: nazwy wydziału i katedry, oznaczenia stanowiska ${ }^{2}$, tytułu naukowego, numeru identyfikacyjnego pracownika);

2) danych płacowych pracowników dydaktycznych (w przekroju poszczególnych składników kosztów osobowych);

3) wykonania planu zajęć;

4) studentów (na jakim wydziale, na jakiej specjalności i na którym kierunku studiują).

Dane osobowe pracowników dydaktycznych znajdują się w zintegrowanym systemie informatycznym. Na Uniwersytecie Ekonomicznym we Wrocławiu wykorzystuje się system SIMPLE.ERP, który służy do wspomagania zarządzania Uczelnią. Przy odpowiednim dostępie do danych można uzyskać dane osobowe wraz z aktualną strukturą organizacyjną Uczelni na podstawie bazy danych systemu SIMPLE.ERP. Na potrzeby budowy modelu kalkulacji dane są eksportowane za pomocą kreatora połączenia danych w MS Excelu. Na rycinie 1 przedstawiono strukturę tabeli danych uzyskanych z bazy danych SIMPLE.ERP.

\begin{tabular}{|c|c|c|c|c|c|c|}
\hline 1000000000 & Wydział Nauk EkonomicznychNE & $1639 / 2$ & Prodziekan & Dorota & Kwiatkowska & 1950 \\
\hline 1000000000 & Wydział Nauk EkonomicznychNE & 193088 & Prodziekan & Bogusław & Kowalski & 2621 \\
\hline 1000000000 & Wydział Nauk EkonomicznychNE & 193454 & Prodziekan & Aleksandra & Kaczorowska & 2730 \\
\hline 1000000000 & Wydział Nauk EkonomicznychNE & 195860 & Dziekan & Czesław & Niedwiedz & 20329 \\
\hline 1012000000 & Biuro Wydziału Nauk-Ekonomicznych & 191396 & pomoc techniczna & Joanna & Romanowa & 1691 \\
\hline 1012000000 & Biuro Wydziału Nauk-Ekonomicznych & 192557 & kierownik Biura & Ewa & Zajączkowa & 2372 \\
\hline 1012100000 & Katedra Ekonomii Ekologicznej & 1188273 & adiunkt & Edwina & Listopadowa & 2993 \\
\hline 1012100000 & Katedra Badań Marketingowych & 1214931 & st.wykładowca ze stopniem & Joanna & Słodka & 3255 \\
\hline 1012100000 & Wydział Ekonomii, Zarządzania i Turystyki & 191648 & Prodziekan & Elżbieta & Biała & 1930 \\
\hline 1012100000 & Wydział Ekonomii, Zarządzania i Turystyki & 191981 & starszy referent & Izabela & Gorzka & 2117 \\
\hline 1012100000 & Wydział Ekonomii, Zarządzania i Turystyki & 193865 & profesor nadzwyczajny UE & Magdalena & Kowalska & 2847 \\
\hline 1012100000 & Wydział Ekonomii, Zarządzania i Turystyki & 194504 & adiunkt & Karina & Toporowa & 2988 \\
\hline 1012100000 & Katedra Zarządzania Jakością i Środowiskiem & 196811 & adiunkt & Artur & Dobry & 3070 \\
\hline 1012100000 & Katedra Zarządzania Jakością i Środowiskiem & $3344 / 2$ & profesor nadzwyczajny UE & Anetta & Jeśminowa & 3344 \\
\hline
\end{tabular}

Ryc. 1. Element tabeli zawierającej informacje dotyczące struktury organizacyjnej Uczelni (dane osobowe są fikcyjne)

Źródło: fragment okna MS Excel.

Dane płacowe pracowników dydaktycznych zostały pozyskane na potrzeby kalkulacji za pośrednictwem oprogramowania klasy BI - ReportPortal (patrz ryc. 2). W tym serwisie w celu otrzymania potrzebnych danych wykorzystuje się moduł PLACE połączony z odpowiednią kostką OLAP. Tak jak wspomniano wyżej, koszty osobowe nauczycieli składają się z wielu elementów. W opisywanym modelu kalkulacji kosztów uwzględniono następujące składniki kosztów osobowych: stawkę zasadniczą, wynagrodzenie ponadwymiarowe, dodatek stażowy, "trzynastkę”, składki chorobowe, zdrowotne, emerytalne, rentowe, płacone przez pracowników i narzuty na wynagrodzenia płacone przez pracodawcę.

Uniwersytet Ekonomiczny we Wrocławiu jest jednym z członków Międzyuniwersyteckiego Centrum Informatyzacji i korzysta z uniwersyteckiego systemu obsługi studiów (USOS). Wszystkie dane dotyczące procesu dydaktycznego są umieszczone w tym systemie. USOS dostarcza raportów (w formacie csv) z wykonania planu zajęć w przekroju poszczególnych nauczycieli i przedmiotów w module Pracownicy. W raporcie znajdują się dane dotyczące nazwiska wykładowcy, kodu przedmiotu, semestru, rodzaju zajęć, liczby godzin i liczby godzin ponadwymiarowych. Strukturę takiego raportu przedstawiono na ryc. 3 .

${ }^{2 n a ~ p r z y k ł a d: ~ d y d a k t y c z n e g o, ~ n a u k o w e g o, ~ d y d a k t y c z n o-n a u k o w e g o . ~}$ 


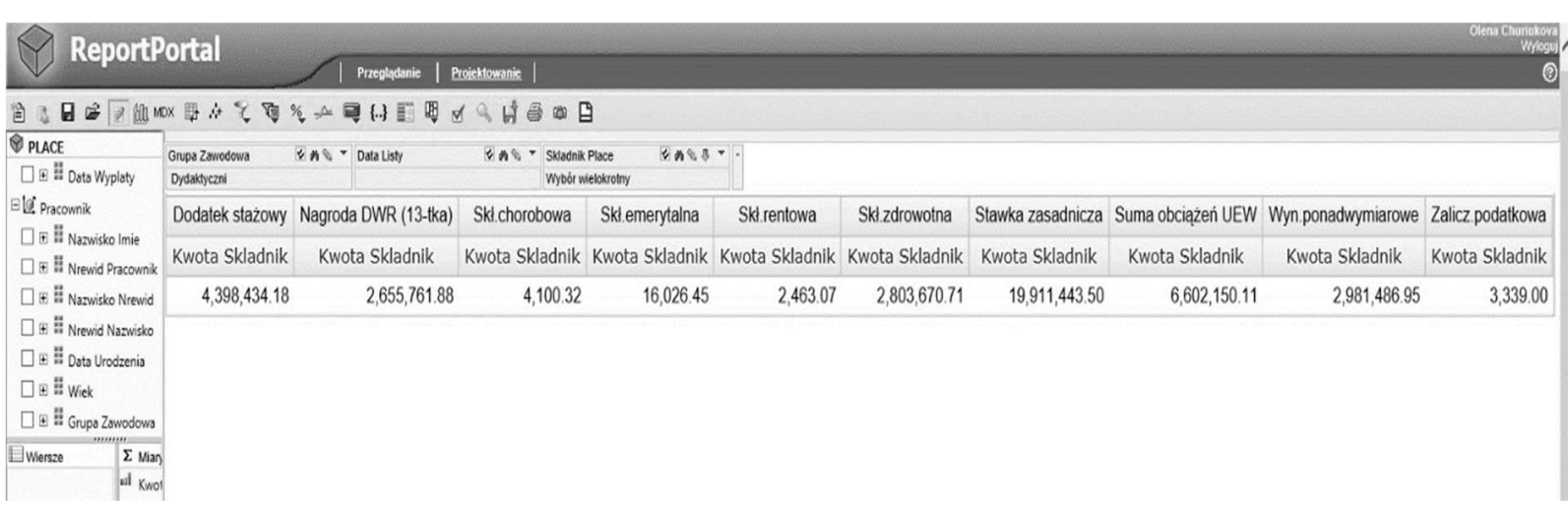

Ryc. 2. Projekt raportu płacowego

Źródło: widok okna ReportPortal.

\begin{tabular}{|c|c|c|c|c|c|c|c|c|c|c|}
\hline 4 & B & c & D & E & $\mathrm{F}$ & G & H & 1 & J & $\mathrm{k}$ \\
\hline 1 L 녀 & P. Imię & Nazwisko & Przedmiot & Opis przedmiotu & Cykl dydaktyczny & Kod typu zajęć & Numer grupy & Liczba osób & Godziny wliczone do pensum & Godziny ponadwymiarowe \\
\hline 2 & 1 Jacek & Nowakowski & 4/000-S2-SM1 & Seminarium dyplomowe-magisterskie I & 2016/17-L & $C ́ W$ & 1 & 4 & 12 & 2 \\
\hline 3 & 2 Jacek & Nowakowski & i 4EK/602-S1-CON-4903 & Controlling & $2016 / 17-\mathrm{L}$ & $c ́$ Ć & 1 & 21 & 10 & 0 \\
\hline 4 & 3 Jacek & Nowakowski & 4DO/000-N3-SD8 & Seminarium doktoranckie & 2016/17-L & ćw & 1 & 1 & 0 & 5 \\
\hline 5 & 4 Jacek & Nowakowski & i $4 / 000-52-5 M 3$ & Seminarium dyplomowe-magisterskie III & $2016 / 17-L$ & ćw & 1 & 1 & 0 & 0 \\
\hline 6 & 5 Jacek & Nowakowski & i/000-N1-SM4 & Seminarium dyplomowe - licencjackie I & 2016/17-L & 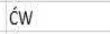 & 1 & 2 & 3 & 0 \\
\hline 7 & 6 Jacek & Nowakowski & 4/000-N2-SM1 & Seminarium dyplomowe - magisterskie I & 2016/17-L & 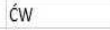 & 1 & 3 & 9 & 0 \\
\hline 8 & 7 Jacek & Nowakowski & 4/000-N2-SM4 & Seminarium dyplomowe - magisterskie IV & 2016/17-L & $c W$ & 1 & 2 & 6 & 0 \\
\hline 9 & 8 Jacek & Nowakowski & i $4 / 000-52-5 M 4$ & Seminarium dyplomowe-magisterskie IV & $2016 / 17-\mathrm{L}$ & 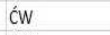 & 1 & 6 & 18 & 0 \\
\hline 10 & 9 Jacek & Nowakowski & 4/000-S1-SM4 & Seminarium dyplomowe- licencjackie I & 2016/17-L & 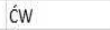 & 1 & 5 & 0 & 7,5 \\
\hline 11 & 10 Jacek & Nowakowski & 4/000-N1-SM6 & Seminarium dyplomowe-licencjackie III & 2016/17-L & $c ́$ ć & 24 & 2 & 6 & 6 \\
\hline 12 & 11 Hanna & Listik & 1GP/000-S2-PRE-1912 & Polityka regionalna & 2016/17-L & $c ́ w$ & 8 & 16 & 2 & 2 \\
\hline 13 & 12 Hanna & Listik & 1FR/000-S1-GPG-1912 & Geografia polityczna i gospodarcza & 2016/17-L & $c ́ w$ & 11 & 27 & 2 & 2 \\
\hline 14 & 13 Hanna & Listik & 1FR/000-S1-GPG-1912 & Geografia polityczna i gospodarcza & 2016/17-L & 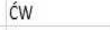 & 12 & 29 & 2 & 2 \\
\hline 15 & 14 Piotr & Kmieczyk & 2ZA/A00-S1-OM2-2303 & Organizational Methods and Techniques & 2016/17-L & 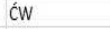 & 1 & 16 & 4 & 4 \\
\hline 16 & 15 Piotr & Kmieczyk & 2LG/000-N1-PP-2303 & Projektowanie procesów & 2016/17-L & $c ́ w$ & 1 & 22 & 5 & 5 \\
\hline 17 & 16 Piotr & Kmieczyk & 2LG/000-N1-PP-2303 & Projektowanie procesów & 2016/17-L & 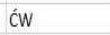 & 2 & 27 & 4 & 4 \\
\hline 18 & 17 Piotr & Kmieczyk & 2LG/000-N1-PP-2303 & Projektowanie procesów & 2016/17-L & ćw & 3 & 24 & 4 & 4 \\
\hline 19 & 18 zbigniew & Rum & 2AG/000-S1-KS-2304 & Komunikacja społeczna & 2016/17-L & 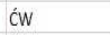 & 1 & 33 & 15 & 5 \\
\hline 20 & 19 Zbigniew & Rum & 2ZA/000-N2-ESB4-2304 & Etyka i społeczna odpowiedzialność biznesu & 2016/17-L & $c ́$ CW & 1 & 18 & 9 & 9 \\
\hline 21 & 20 Zbigniew & Rum & 2AG/000-S1-KS-2304 & Komunikacja społeczna & 2016/17-L & $c w$ & 2 & 16 & 15 & 5 \\
\hline
\end{tabular}

Ryc. 3. Przykładowy raport z wykonania planu zajęć zaimportowany do arkusza kalkulacyjnego (dane osobowe są fikcyjne)

Źródło: fragment okna MS Excel.

Dane osobowe studentów i inne potrzebne dane dotyczące procesu dydaktycznego uzyskuje się nie z samego USOSa, tylko z współpracującej z nim bazy danych Oracle. Na potrzeby kalkulacji zostały utworzone odpowiednie widoki zawierające kody studentów i wybrane przez nich kierunki oraz specjalności. Widoki posiadają również słowniki nazw kierunków i specjalności wraz ze stosowanymi kodami. Uzyskane dane można bezpośrednio importować do MS Excela. Na ryc. 4 pokazano fragment okna aplikacji służącej do pobierania danych z Oracle - SQL Deweloper.

Posiadając przedstawione dane i używając odpowiedniej aplikacji, można wykonać model kalkulacji kosztów kształcenia w przekroju wszystkich kierunków i specjalności. Na potrzeby realizacji tego modelu została stworzona aplikacja, która:

- umożliwia sprawną kalkulację kosztów kształcenia;

- dostarcza dokładnych informacji o wysokości kosztów kształcenia dla władz Uczelni;

- pozawala na dokładne planowanie kosztów specjalności, kierunku studiów, jednostek organizacyjnych Uczelni;

- generuje szczegółowe informacje o kosztach dydaktycznych w ujęciu planu rzeczowo-finansowego. 
Na ryc. 5 został zaprezentowany schematycznie proces przetwarzania danych w aplikacji.

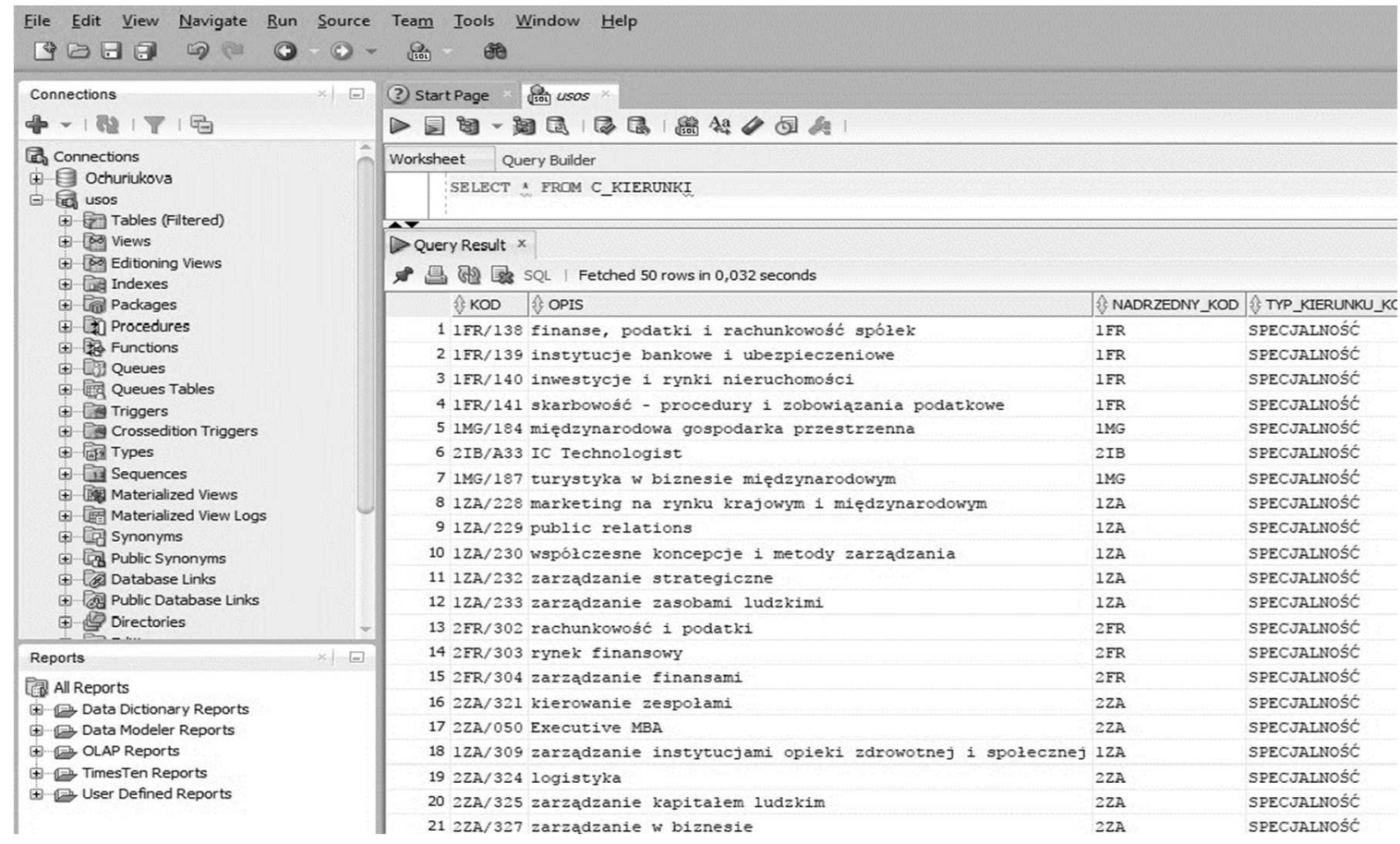

Ryc. 4. Przykładowy widok z bazy danych USOS

Żródło: fragment okna SQL Deweloper.

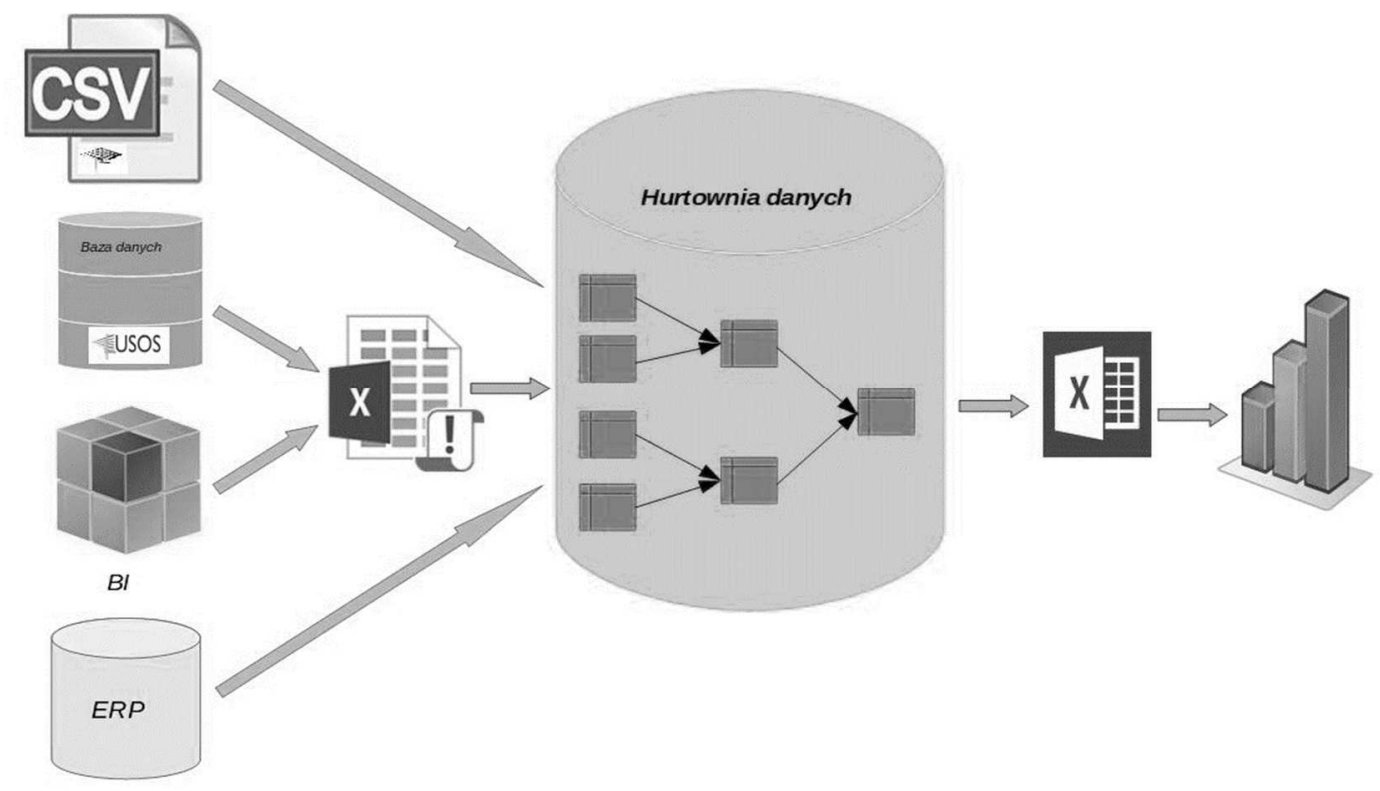

Ryc. 5. Schemat przetwarzania danych w aplikacji służącej do kalkulacji kosztów osobowych nauczycieli akademickich

Źródła danych oraz narzędzie do ich pozyskiwania pokazują, jak bardzo jest skomlikowany proces kalkulacji kosztów działalności dydaktycznej na uczelni publicznej. Warto dodać, że Uczelnia posiada prawa własności do tych danych, co wiąże się z bezkosztowym dostępem do nich. Ponadto dane te jednostka posiada bez względu na to, czy proces kalkulacji jest realizowany na podstawie danych planistycznych czy rzeczywistych. 


\section{PROCEDURA KALKULACJI KOSZTÓW OSOBOWYCH NA PRZYKŁADZIE UNIWERSYTETU EKONOMICZNEGO WE WROCŁAWIU}

Procedura kalkulacji kosztochłonności kierunków w zakresie kosztów osobowych pracowników dydaktycznych polega na oszacowaniu stawki godzinowej zajęć każdego z nauczycieli akademickich oraz agregacji danych kosztowych w przekroju konkretnej edycji kierunku studiów, z podziałam na tryb stacjonarny i niestacjonarny oraz na I i II stopień. Poszczególne edycje mogą być realizowane w okresie od 2 do 3 lat, co wiąże się z koniecznością doliczania do nich kosztów pośrednich po każdym roku akademickim. Po zakończeniu edycji będzie możliwe obliczenie jej kosztów całkowitych oraz kosztu jednostkowego absolwenta.

Kalkulacja kosztów dydaktyki w zakresie kosztów osobowych przebiega wieloetapowo. W tab. 1 przedstawiano jej poszczególne etapy.

Tabela 1. Etapy procesu kalkulacji

\begin{tabular}{|c|c|c|c|}
\hline $\begin{array}{c}\mathrm{Nr} \\
\text { etapu }\end{array}$ & Wynik & $\begin{array}{l}\text { Źródła } \\
\text { danych }\end{array}$ & Uwagi \\
\hline 1 & $\begin{array}{l}\text { T1 - roczne koszty osobowe } \\
\text { związane z dydaktyką w przekroju } \\
\text { pracowników }\end{array}$ & $\begin{array}{l}\text { System BI } \\
\text { powiązany z } \\
\text { SIMPLE } \\
\text { ERP }\end{array}$ & $\begin{array}{l}\text { Jeżeli jakiś składnik wynagrodzeń dotyczy dzia- } \\
\text { łalności dydaktycznej i naukowej, stosowany } \\
\text { jest dla niego wskaźnik podziału D/N. Jeżeli } \\
\text { jakiś składnik wynagrodzeń nie dotyczy dzia- } \\
\text { łalności dydaktycznej, nie jest uwzględniany, } \\
\text { np. wynagrodzenie z tytułu pracy przy pro- } \\
\text { jekcie badawczym }\end{array}$ \\
\hline 2 & $\begin{array}{l}\text { T2 - zrealizowana liczba godzin } \\
\text { dydaktycznych w roku akademickim } \\
\text { w przekroju pracowników, przed- } \\
\text { miotów, trybu i stopnia studiów oraz } \\
\text { kierunków studiów }\end{array}$ & USOS & $\begin{array}{l}\text { Należy pamiętać, że niektóre przedmioty są } \\
\text { realizowane na wielu kierunkach, np. języki } \\
\text { obce czy wychowanie fizyczne }\end{array}$ \\
\hline 3 & $\begin{array}{l}\text { T3 - stawka godzinowa dla po- } \\
\text { szczególnych pracowników }\end{array}$ & T1 i T2 & $\begin{array}{l}\text { Na podstawie ilorazu kosztów osobowych } \\
\text { danego pracownika i liczby godzin przez niego } \\
\text { przepracowanych w roku akademickim obli- } \\
\text { czany jest koszt jednostkowy godziny lekcyjnej }\end{array}$ \\
\hline 4 & $\begin{array}{l}\text { T4 - zrealizowana liczba godzin } \\
\text { dydaktycznych dla przedmiotów } \\
\text { poza kierunkiem studiów w roku } \\
\text { akademickim, dotycząca studentów, } \\
\text { pracowników, przedmiotów, trybu } \\
\text { i stopnia studiów }\end{array}$ & T2 & $\begin{array}{l}\text { Podział godzin zrealizowanych poza kie- } \\
\text { runkiem następuje na podstawie studentów } \\
\text { przypisanych do tego przedmiotu }\end{array}$ \\
\hline 5 & $\begin{array}{l}\text { T5 - lista studentów w przekroju } \\
\text { kierunków }\end{array}$ & USOS & $\begin{array}{l}\text { Dane te pozwalają na podział kosztów } \\
\text { osobowych, które zostały obliczone bez przy- } \\
\text { pisanego kierunku studiów }\end{array}$ \\
\hline 6 & $\begin{array}{l}\text { T6 - liczba godzin dydaktycznych } \\
\text { przypisana do kierunku, z podziałem } \\
\text { na studentów, pracowników, przed- } \\
\text { mioty, tryby i stopnie studiów oraz } \\
\text { kierunki studiów }\end{array}$ & T4 i T5 & $\begin{array}{l}\text { Podział godzin zrealizowanych w ramach } \\
\text { przedmiotu na kierunki następuje na podstawie } \\
\text { studentów danego kierunku przypisanych do } \\
\text { tego przedmiotu }\end{array}$ \\
\hline 7 & $\begin{array}{l}\text { T7 - częściowe koszty osobowe } \\
\text { przypisane do poszczególnych kie- } \\
\text { runków }\end{array}$ & T3 i T6 & $\begin{array}{l}\text { Koszty te są obliczane jako iloczyn stawek } \\
\text { godzinowych i czasu pracy danego pracownika } \\
\text { przypisanego do studenta z danego kierunku. } \\
\text { Obliczone koszty dotyczą tylko części przed- } \\
\text { miotów, które nie miały przypisanych kierunków }\end{array}$ \\
\hline 8 & $\begin{array}{l}\text { T8 - częściowe koszty osobowe } \\
\text { przypisane do poszczególnych kie- } \\
\text { runków }\end{array}$ & T2 i T3 & $\begin{array}{l}\text { Koszty te są obliczane jako iloczyn stawek } \\
\text { godzinowych oraz zrealizowanej liczby godzin } \\
\text { w przypadku przedmiotów, gdy był wskazany } \\
\text { kierunek }\end{array}$ \\
\hline 9 & $\begin{array}{l}\text { T9 - łączne koszty osobowe, z po- } \\
\text { działem na kierunki }\end{array}$ & T7 i T8 & \\
\hline
\end{tabular}


Jak można zauważyć, proces kalkulacji kosztów osobowych poszczególnych kierunków w danym roku akademickim jest złożony. Warto jednak pamiętać, że w przypadku posiadania bezpośrednich łączy do danych źródłowych oraz aplikacji umożliwiającej wykonanie poszczególnych kroków przeprowadzenie obliczeń jest stosunkowe proste oraz szybkie. Dzięki temu możliwe jest generowanie raportów na żądanie dla odpowiednich służb Uczelni, pozwalające na bieżącą kontrolę kosztów osobowych w przekroju poszczególnych obiektów kosztowych. W przyszłości oczekuje się, że to podejście zostanie uzupełnione o pozostałe rodzaje kosztów i stanie się podstawowym narzędziem controllingowym w ramach struktur Uczelni.

\section{PODSUMOWANIE}

Przedstawiona w opracowaniu procedura kalkulacji kosztów osobowych działalności dydaktycznej jest jednym z kroków podejmowanych przez pracowników naukowych (katedr zajmujących się problematyką rachunku kosztów oraz controllingu), pracowników działu controllingu oraz pracowników działu informatyki w kierunku budowy informacyjnego systemu controllingu. Zaangażowanie tak dużego zespołu wynika ze specyfiki kosztów działalności dydaktycznej i przetwarzanych baz danych. Aktualna sytuacja polskich szkół wyższych sprzyja poszukiwaniu efektywnych narzędzi zarządzania kosztami, dlatego należy spodziewać się dużego zainteresowania w środowisku uczelnianym omawianą problematyką, jak również przedstawianymi koncepcjami czy narzędziami informatycznymi.

Prezentowane podejście ma oczywiście pewne wady oraz początkowy stopień zaawansowania, jednakże niskie koszty tego rozwiązania, również korzystanie z zasobów własnych pozwalają na bardzo optymistyczne wnioski dotyczące efektów prac.

Jako materiał do dyskusji autorzy wskazują: uproszczenie procedury kalkulacji, rozwiązania problemu subiektywizmu podziału składników wynagrodzeń związanych z działalnością dydaktyczną i naukową, uwzględnianie kosztochłonności różnych form zajęć (wykładów w językach obcych, zajęć w laboratoriach specjalnościowych), możliwości ewidencji rzeczywistego czasu pracy nauczyciela (z uwzględnieniem przygotowania się do zajęć, sprawdzania postępów w nauce, konsultacjami itp.).

\section{PIŚMIENNICTWO}

Małys K. 2016. Analiza struktury kosztów w publicznych szkołach wyższych w Polsce. Pr. Nauk. UE Wroc. 442, 278-289.

Miłosz H. 2003. Analiza kosztów kształcenia w szkołach wyższych. Legnica, Wydaw. Wspólnota Akademicka.

Rozporządzenie Ministra Nauki i Szkolnictwa Wyższego z dnia 2 grudnia 2016 r. w sprawie warunków wynagradzania za pracę i przyznawania innych świadczeń związanych $z$ pracą dla pracowników zatrudnionych w uczelni publicznej. DzU z 2016 r., nr 243, poz. 1447.

Rozporządzenie Rady Ministrów z dnia 18 grudnia 2012 roku w sprawie szczegółowych zasad gospodarki finansowej uczelni publicznej. DzU z 2012 r., poz. 1533, par. 8.

Świderska G. 2008. Rachunek kosztów i rachunkowość zarządcza. Warszawa, Wydaw. Stow. Księg. w Polsce.

Uchwała Senatu Uniwersytetu Ekonomicznego we Wrocławiu nr R.0000.15.2017 z dnia 23 lutego 2017 r. w sprawie zasad planowania i rozliczania zajęć dydaktycznych w roku akademickim 2017/2018, http://www.ue.wroc.pl/p/dla_pracownikow/uchwaly_senatu_2017/us66_2017.pdf, dostęp: 20.11.2017. 
Ustawa z dnia 29 września 1994 r. o rachunkowości. DzU z 2018 r., poz. 395 z późn. zm.

Ustawa z dnia 27 lipca 2005 r. Prawo o szkolnictwie wyższym. DzU z 2005 r., nr 164, poz. 1365.

Wermut J. 2006. Rachunkowość zarządcza. Gdańsk, Wydaw. Ośrodek Doradztwa Doskonalenia Kadr.

Zarządzenie nr 64/2017 Rektora Uniwersytetu Ekonomicznego we Wrocławiu z dnia 30 września 2017 r. w sprawie stawek wynagrodzenia za pracę $z$ godzinach ponadwymiarowych na studiach stacjonarnych i niestacjonarnych pierwszego, drugiego i trzeciego stopnia oraz stawek wynagrodzenia za prowadzenie zajęć dydaktycznych przez osoby niezatrudnione w Uczelni na studiach stacjonarnych i niestacjonarnych pierwszego, drugiego i trzeciego stopnia w roku akademickim 2017/2018, http://www.ue.wroc.pl/p/dla_pracownikow/zarzadzenia_ _pisma_okolne_rektora2017/zarzadzenie_rektora_nr_64_2017.pdf, dostęp: 20.11.2018.

Streszczenie. Skuteczne zarządzanie uczelnią publiczną wymaga przetwarzania wielu danych. Rentowność poszczególnych rodzajów działalności jest determinowana przez ich przychody i koszty. Na koszty dydaktyki składają się głównie koszty osobowe (wynagrodzenia plus narzuty na wynagrodzenia) profesorów, adiunktów, asystentów, lektorów i in. Właściwe przetwarzanie danych kosztowych wymaga wdrożenia zaawansowanych metod kalkulacji. W związku z tym celem artykułu jest prezentacja procedury kalkulacji kosztów osobowych nauczycieli akademickich na uczelni publicznej. Procedura umożliwia ustalenie kosztów kształcenia w ramach poszczególnych kierunków studiowania. Na podstawie studium przypadku przedstawiano aspekty funkcjonowania rachunku kosztów, problematyki pozyskania danych potrzebnych do kalkulacji oraz zasad ich przetwarzania. Jako przykład posłużył Uniwersytet Ekonomiczny we Wrocławiu; dane wykorzystane $\mathrm{w}$ modelu kalkulacji pochodziły $\mathrm{z}$ roku akademickiego $2016 / 2017$. 